\title{
Analytic Theology and Analytic Philosophy of Religion: What's the difference?
}

\author{
Max Baker-Hytch \\ University of Notre Dame
}

\begin{abstract}
Analytic theology is often seen as an outgrowth of analytic philosophy of religion. It isn't fully clear, however, whether it differs from analytic philosophy of religion in some important way. Is analytic theology really just a sub-field of analytic philosophy of religion, or can it be distinguished from the latter in virtue of fundamental differences at the level of subject matter or methodology? These are pressing questions for the burgeoning field of analytic theology. The aim of this article, then, will be to map out several forms that analytic theology might (and in some cases actually does) take before examining the extent to which each can be thought to be distinct from analytic philosophy of religion.
\end{abstract}

\section{Introduction}

The recent emergence of analytic theology appears to have rekindled interest in the age-old question of what exactly it is that distinguishes the intellectual disciplines of theology and philosophy from one another. ${ }^{1}$ And it's no surprise that it has done so. After all, analytic theology is at present practiced mostly by analytic philosophers of religion who have begun turning their focus towards a cluster of topics that were traditionally the preserve of systematic theologians: trinity, incarnation, atonement, resurrection, sin, grace, the Holy Spirit, the church, the sacraments, and so on. It makes sense that these philosophers trained in the analytic tradition should pause to wonder whether they might in fact be entering terrain that is fundamentally different in some way from that with which they had previously been familiar. Indeed, although analytic theology is often seen as an outgrowth of analytic philosophy of religion, it isn't fully clear to what extent it might differ from analytic philosophy of religion in some important way. Those conventional theologians who are presently wary of analytic theology may worry that it is really no different at all from analytic philosophy of religion. Are they right? Is analytic theology really just a sub-field of analytic philosophy of religion? This is a pressing question indeed for the burgeoning field of analytic theology. The aim of this article, then, will be to map out several forms that analytic theology might (and in some cases actually does) take before examining the extent to which each can be thought to be distinct from analytic philosophy of religion.

\footnotetext{
${ }^{1}$ See, for instance, Wood (2014), Stump (2013), Abraham (2013), Wolterstorff (2009), and
} Chignell (2009).

Journal of Analytic Theology, Vol. 4, May 2016

10.12978/jat.2016-4.120023010007a

(C)2016 Max Baker-Hytch • (C) 2016 Journal of Analytic Theology 


\section{What is analytic philosophy of religion?}

Before proceeding any further it will be helpful if we can offer at least a rough characterization of analytic philosophy of religion. There are several dimensions along which we might try to characterize the discipline, including its methodology, its subject matter, and its historical development as an intellectual tradition. Beginning with the last of these, the rise of analytic philosophy of religion is really an innovation of the latter half of the twentieth century. It began to take root in the wake of the widespread abandonment of the strongly antimetaphysical doctrine of logical positivism around the middle of the twentieth century, and the growth of analytic philosophy of religion as a field was subsequently catalysed by several crucial developments in analytic metaphysics and epistemology in the ensuing decades. ${ }^{2}$ Some of the most notable of these include the development of possible worlds semantics as a heuristic for investigating necessity and possibility, the recognition of the category of metaphysical necessity and possibility as distinct from strict logical necessity and possibility, the refutation of the traditional tripartite account of knowledge by Gettier's cases and the subsequent rise of externalist accounts of knowledge according to which knowledge can be had in the absence of evidence or reasons as traditionally construed, and the application of formal approaches to epistemology which make use of Bayesian probabilistic conditionalization and decision theory. As an intellectual tradition, analytic philosophy of religion can also be characterized in terms of the relation of its practitioners to the great thinkers of the past. The typical approach taken by analytic philosophers in this regard is to look to the writings of historical thinkers primarily as a source of arguments and theories that can be translated into an analytic idiom and used to advance contemporary debates. Historical figures upon whom analytic philosophers of religion tend to draw in this fashion include medievals such as Anselm, Aquinas, Duns Scotus, and Ockham, as well as thinkers of the early modern period such as Descartes, Hume, Reid, Kant, and Leibniz.

At the level of methodology, analytic philosophy of religion can be seen as applied analytic metaphysics and epistemology. ${ }^{3}$ As such it employs the following sorts of methods: thought experiments and intuition pumps; reasoning by analogy; attempting to achieve reflective equilibrium between intuitions and theoretical principles; offering analyses in terms of necessary and sufficient conditions; refining analyses and principles by way of counterexample (also known as 'Chisholming'); appealing to theoretical devices such as possible worlds and sets; using probabilistic frameworks such as Bayesian confirmation theory and formal languages such as predicate logic and modal logic in order both to state arguments with precision and to examine the consequences of philosophical theories; appealing to explanatory virtues such as simplicity, elegance, and explanatory power as a guide to theory-choice; and where appropriate, appealing

\footnotetext{
${ }^{2}$ For a fuller historical account of the rise of analytic philosophy of religion, see Wolterstorff (2009).

${ }^{3}$ Recent accounts of the methodology of analytic metaphysics and epistemology can be found in Williamson (2007), Rea (2009a), and van Inwagen (2006b).
} 
to philosophically relevant portions of well-established scientific theories. Analytic philosophy of religion can also be seen to share with analytic metaphysics and epistemology a set of stylistic aspirations, most notably, a striving to state arguments and theories in a maximally precise form and to use words in their everyday senses except in the case of technical terms that are given explicit definitions, where those definitions are expected ultimately to bottom out in wellunderstood terms used in their everyday senses.

Importantly, the foregoing characterization of the methodology of analytic philosophy of religion is based simply on observations about the methods that are employed in what I take to be paradigm examples of works of analytic philosophy of religion, such as Richard Swinburne's The Existence of God (2004), Alvin Plantinga's Warranted Christian Belief (2000), Peter van Inwagen's The Problem of Evil (2006a), William Alston's Perceiving God (1991), Brian Leftow's Time and Eternity (1991), J.L. Mackie's The Miracle of Theism (1982), and so on. I certainly don't mean to claim that the methodology just sketched can be derived a priori from some eternal essence of analytic philosophy of religion.

As for its subject matter, I think we can fairly easily circumscribe the range of questions and topics that fall within the remit of analytic philosophy of religion. George Bealer (1998: 203-204) has suggested that analytic philosophy studies those subject matters that are characterised by three especially noteworthy features: universality, generality, and necessity. That is, it addresses those questions which are universal in the sense that they are of relevance to rational creatures regardless of their historical and social circumstances, which are general in the sense that they don't pertain to particular individuals or events, and which call for answers that are true of necessity. Analytic philosophy of religion, then, is the branch of analytic philosophy that treats questions which are of this character and which concern religiously significant topics such as God, the afterlife, religious belief, faith, religious experience, and so on. ${ }^{4}$

\section{Where to look for differences}

I suggested earlier that analytic theology might be seen as an outgrowth of analytic philosophy of religion, and I suspect that many would concur with this characterisation. One way to read this remark is as a comment on the historical lineage of analytic theology as an intellectual tradition. But can analytic theology be distinguished from analytic philosophy of religion with respect to its character as an intellectual tradition? Well, just as those descendants of Europeans who migrated to North America gradually formed a cultural identity which is now markedly different from that of Europe, it may be that analytic theology will eventually come to constitute a decidedly distinct intellectual tradition from its forebear, but I would suggest that that stage has not yet been reached. The overlap

\footnotetext{
${ }^{4}$ One might wonder if some of the questions treated by analytic philosophy of religion really fit Bealer's characterisation. For instance, analytic philosophy of religion deals with the question of whether this world is the product of a supernatural creator, and whether the amounts and kinds of evil found in this world are compatible with the existence of a loving God. I think it can be seen, however, that these questions do have a perfectly general form: they are questions about whether it is possible or probable that a deity of some description should co-exist with certain types of states of affairs.
} 
between the practitioners of the two is very large at present and hence they can scarcely be said to constitute distinct intellectual communities, but besides, analytic theology hasn't yet had time to develop a substantial written corpus of its own, the having of which is plausibly an essential part of something's being an intellectual tradition.

Another place to look for deep differences is at the level of subject matter. It has been suggested that the distinction between analytic philosophy of religion and analytic theology can be drawn in this way. ${ }^{5}$ Specifically, the idea is that analytic philosophy of religion investigates questions pertaining to theism in general, whereas analytic theology investigates those questions that pertain to claims about God which are found in the Christian religious tradition in particular. I am dubious about this as a way of getting a handle on what really sets the two disciplines apart, however. For one thing, if the idea here is that analytic philosophy of religion deals with religious ideas and propositions which are tradition-transcending (i.e. which are accepted by more-or-less all religious traditions), then it is far from clear that analytic philosophy of religion actually conforms to this ideal. Rather, the focus in practice is largely upon Anselmian perfect-being theism and Abrahamic monotheism, which are not views that are held by all or almost all religious traditions. For another thing, there really seems to be no principled reason for saying that theories or claims about divinity which are found only in certain traditions lie beyond the investigative remit of analytic philosophy of religion. The fact that a given claim has been believed only by some cultures or traditions should have no bearing on whether the claim in question is a fit object for investigation by analytic philosophers of religion. All that should matter is whether the claim in question would constitute an answer to what is recognizably a philosophical question-a question such as 'What properties must a divine being have?' or 'What sort of afterlife ought we to desire?'

\section{Differences in methodology?-The appeal to scripture and tradition}

Having rejected ways of distinguishing analytic theology and analytic philosophy of religion which appeal to supposed differences in their identities as intellectual traditions and in their subject matters, we now turn to what I take to be the most interesting respect in which we might try to distinguish the two, namely, methodology. Now, I take it that the reason that analytic theology is called analytic theology is that it aspires to make use of those analytic philosophical methods to which I alluded in my earlier characterisation of analytic philosophy of religion. At the same time, isn't it the case that analytic theology additionally employs a certain method that analytic philosophy of religion does not and cannot, namely, appealing to scripture and ecclesial tradition? Historically, of course, a very influential thought about what distinguishes theology from philosophy at the

\footnotetext{
${ }^{5}$ See, for instance, Plantinga (1992: 291). Plantinga here talks about 'philosophical theology' rather than 'analytic theology.' As far as I can tell analytic theology just is analytic philosophical theology, but in any case, what Plantinga says about the former seems fully applicable to the latter in this regard.
} 
level of methodology has been that theology involves such appeals whereas philosophy doesn't-philosophy appeals to reason alone. ${ }^{6}$ Andrew Chignell echoes this thought in a recent piece:

Philosophy of religion involves arguments about religiously pertinent philosophical issues, of course, but these arguments are customarily constructed in such a way that, ideally, anyone will be able to feel their probative force on the basis of 'reason alone.' Analytic theology, by contrast, appeals to sources of topics and evidence that go well beyond our collective heritage as rational beings with the standard complement of cognitive faculties. (2009: 119)

I concur with Chignell that this is the right place to look for fundamental differences, but more needs to be said about exactly what might be involved in appealing to scripture and tradition. In fact, I can think of at least three distinct activities that could be denoted by the phrase 'appealing to scripture and tradition,' namely: (i) looking to scripture or ecclesial tradition as a source of topics for investigation; (ii) citing claims made by scripture or ecclesial tradition in order to try to demonstrate what is entailed by Christian theism; (iii) using a claim asserted by scripture or ecclesial tradition as a premise in an argument.

I should note that 'a premise in an argument,' as I intend the notion here, need not be something so formal as a numbered step in a deductive syllogism, although it includes that sort of thing. Rather, I mean the notion of a premise to apply to any proposition that is offered by a writer as a reason in support of a distinct proposition that he or she is seeking to establish. I should now like to say quite a bit more about the various ways in which one might treat scriptural or tradition-based claims as premises.

When a writer uses a certain claim $p$ as a premise in an argument, she may or may not have anything further to say by way of argument in favour of $p$. It is typical for analytic philosophers to seek to defend at least those premises of their arguments which they take to be controversial among their peers. Of course, an argument offered in favour of a given premise will itself employ premises, and one cannot go on forever arguing for the premises of the argument for the premises of one's argument and for the premises of the argument for the premises of the argument for the premises of one's argument and so on; one must stop somewhere. We can make a distinction, then, between two sorts of premise. On the one hand there is what we might call a foundational premise, on behalf of which no further argumentation is offered, and on the other hand there is what we might call an intermediate premise, which is a premise on behalf of which further argumentation is offered. The chain of reasoning offered in support of any intermediate premise will of course eventually terminate in foundational

\footnotetext{
${ }^{6}$ Aquinas appears to invoke this idea in the following passage: "Sciences are differentiated according to the various means through which knowledge is obtained... in order that the salvation of men might be brought about more fitly and more surely, it was necessary that they should be taught divine truths by divine revelation. It was therefore necessary that besides philosophical science built up by reason, there should be a sacred science learned through revelation" (Aquinas 1981 [1273]: I.I.I).
} 
premises. We can thus distinguish between approaches that treat scriptural or tradition-based claims as foundational premises and approaches that treat such claims as intermediate premises.

Let's consider further those approaches that treat scriptural or traditionbased claims as intermediate premises. There is an important difference between using a proposition $p$ that is asserted by scripture or ecclesial tradition as an intermediate premise whilst arguing for the truth of the particular claim at issue (i.e. $p$ ), and using a proposition $p$ that is asserted by scripture or ecclesial tradition as an intermediate premise whilst arguing that scripture or tradition are generally trustworthy sources, without arguing for $p$ in particular. To illustrate the difference, suppose that an analytic theologian writes a paper in which ten separate scriptural claims are used as premises at various points in the paper, and suppose further that she intends to treat these scriptural claims as intermediate rather than foundational premises. On the one hand, our analytic theologian might try to offer separate arguments for the truth of each of these ten scriptural claims. On the other hand, she might just offer a general argument for thinking that scripture as a whole is reliable, without trying to offer arguments on behalf of each individual scriptural claim of which she makes use. Presumably the former is a much more onerous task than the latter.

I take it that we can further distinguish two sub-varieties of the former approach: there are approaches that seek to argue for particular scriptural or tradition-based claims in a way that doesn't assume the truth of scripture or tradition, and there are approaches which argue for particular scriptural or tradition-based claims in a manner that does ultimately assume the truth of some other scriptural or tradition-based claims. As for the latter approach, presumably if one is assuming the truth of certain scriptural passages in order to argue for the trustworthiness of other scriptural passages, then one will be looking only to assume scriptural passages that are widely accepted by one's target audience in order to argue for the truth of (a certain interpretation of) a passage which is more controversial among that audience. ${ }^{7}$

As for arguing for the general trustworthiness of scripture or tradition, again we can distinguish various distinct ways of going about such a task. Firstly, we can distinguish between epistemically circular and non-circular ways of arguing for the trustworthiness of scripture or tradition. To illustrate what I mean by 'epistemic circularity' in this context, consider the following example. Suppose that I am challenged by a Humean sceptic to demonstrate that my visual faculties are trustworthy, and suppose that in order to try to meet this challenge I appeal to various sources such as the results of my optometric tests, physicians' reports, as well as more general scientific accounts of the workings of human visual perception. Of course, if pressed by the sceptic on how I know that these sources are trustworthy, I will eventually have to appeal to things that I take myself to know via my visual perception, and in that sense my defence of the trustworthiness of my visual faculties is epistemically circular. It's worth noting that some epistemologists think that this sort of circularity can be perfectly acceptable, perhaps even epistemically virtuous. ${ }^{8}$ So, one way to defend the general trustworthiness of scripture or tradition is to do so in an epistemically

\footnotetext{
${ }^{7}$ N.T. Wright seems to take something like this approach in chapter 7 of Borg and Wright (2000).

${ }^{8}$ See, for example, Sosa (2009), Van Cleve (2003), and Alston (1986).
} 
circular manner; that is, to tell a story about why we should trust scripture or tradition but in a way that eventually appeals to claims made by scripture or tradition. Here would be an example of such a story: The Gospel narrative which is at the heart of Christian scripture-of God becoming human and dying so as to make humankind right with God-resonates at a deep level with our sense of what might be termed 'narrative fittingness.' Moreover, the reason that this sense should be trusted as a guide to the ultimate truth of things is that scripture gives us reason to think that God would create us with just such a sense.

How might one tell an epistemically non-circular story about the trustworthiness of scripture or tradition? Well, one way would be to mount a kind of inductive argument which goes something like this: There is a range of scriptural or tradition-based claims each of which can be independently verifiedfor instance, by way of archaeological discoveries or corroboration by extraBiblical textual sources-and since scripture has got it right in these instances we may infer that it has probably also got it right about those of its claims that are hard or impossible to verify in a similar manner. A problem with a popular way of running this sort of argument is that it isn't really clear that it is legitimate to infer the trustworthiness of the Bible on all or most topics about which it makes assertions (including metaphysical-doctrinal matters) from the fact that it can be independently shown to be accurate on a certain relatively narrow range of topics such as place names, broad chronology, the existence of certain key figures such as Jesus and St. Paul, and so on. A different approach would be to argue for the truth of one or two particularly important doctrines-say, the Resurrection and the Incarnation-and do so without presupposing the trustworthiness of the Bible, and then go on to argue that the truth of these particular doctrines entails or makes it very probable that the Bible as a whole (or at least, the most theologically significant portions thereof) is trustworthy. Yet another approach would be to appeal to a priori intuitions about what God would be likely to do visa-vis communicating with human beings. One might try to argue that it is a priori probable that God would reveal himself to humans in something like the way that the Bible claims he has done: by becoming incarnate at a particularly religiously poignant place and time in human history and by acting self-sacrificially so as to atone for human sin.

\section{More and less philosophical forms of analytic theology}

Having catalogued fairly extensively the range of possibilities for how one might 'appeal to' scripture and tradition, we should be better positioned to get clear on how various possible forms of analytic theology may or may not differ from analytic philosophy of religion at the level of methodology. At this point it may be helpful, where possible, to point to some concrete examples of each of the forms of analytic theology identified. below.

For convenience, the foregoing distinctions are set out in the diagram 


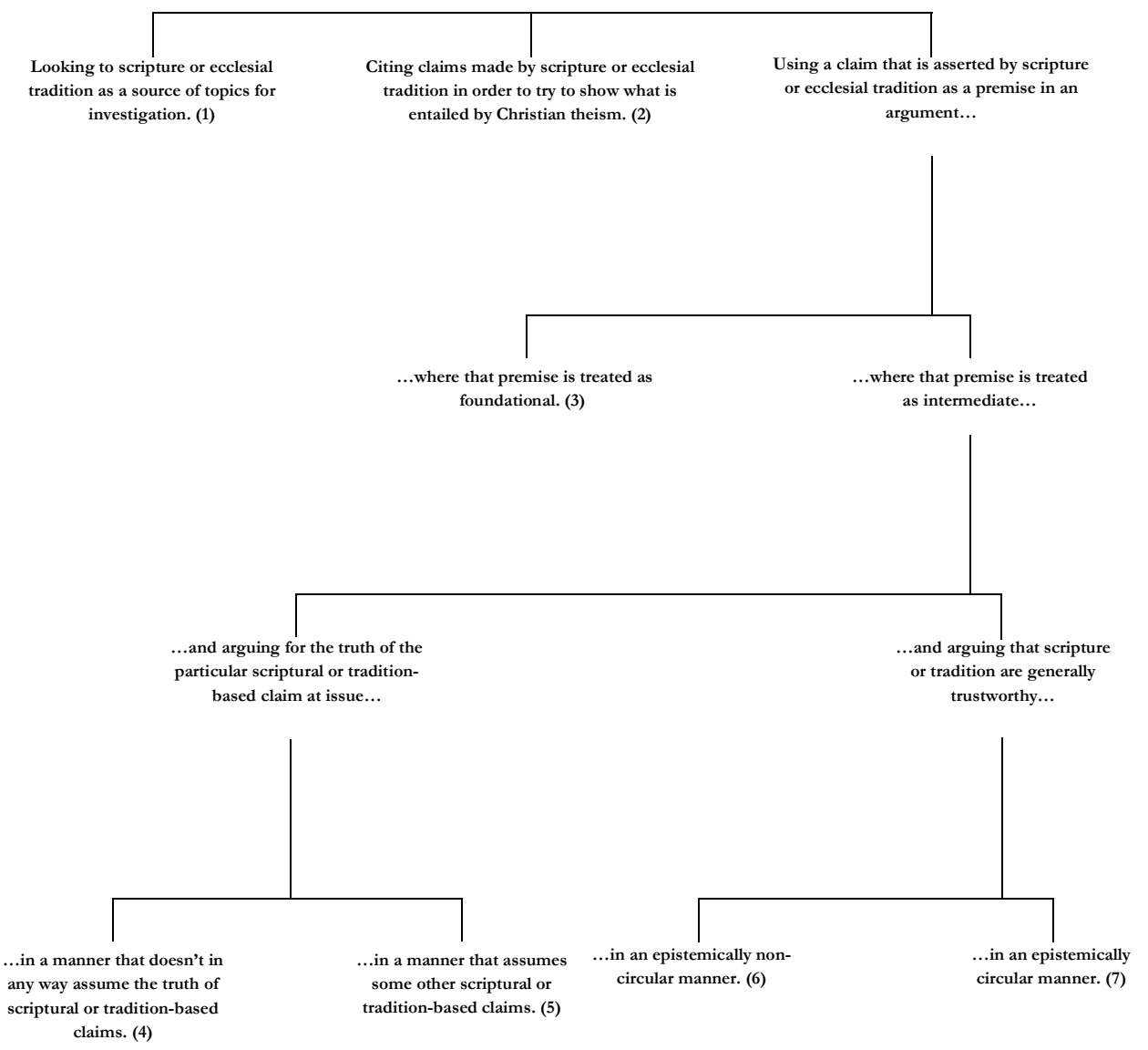

Let's first consider a form of analytic theology that appeals to scripture only in way (1). This sort of analytic theology looks to the scriptures and Christian tradition for interesting topics, but in treating those topics employs only the methods of analytic philosophy of religion sketched earlier. This form of analytic theology really is a sub-field of analytic philosophy of religion, since the only possible reason for calling it 'theology' is its subject matter-namely, those doctrines that are peculiar to the Christian tradition-and I argued that the subject matter of analytic philosophy of religion does in fact encompass the examination of religious claims that are made only by some religious traditions rather than by all. An excellent example of approach (1) is David Lewis's article 'Do We Believe in Penal Substitution?' (1997). Lewis here is simply using the fact that significant portions of the Christian theological tradition affirm the doctrine of penal substitution as an occasion to discuss the question of whether it is ever possible for one person to absorb another person's guilt. There is clearly no sense in which Lewis relies upon scriptural claims in order to justify the conclusions he draws; rather, those conclusions are arrived at solely via the methods of thought experiment and conceptual analysis.

How about a form of analytic theology that appeals to scripture and tradition only in way (2)? I am inclined to think that this too would really be a subfield of analytic philosophy of religion. Again, subject matter alone is not sufficient to distinguish a given form of analytic theology from analytic philosophy of 
religion. And employing a methodology which involves using those aforementioned analytic philosophical tools and appealing to scriptural or tradition-based claims in order to draw out the implications of Christian theism does not require one to take any stand on the truth or trustworthiness of Christian scripture or tradition. In essence, this form of analytic theology would be about arguing for (or against) conditional propositions of the form if Christian theism were true (and hence Christian scripture trustworthy), then $p .^{9}$ It is a point of elementary logic that one can endorse the conditional proposition if $A$, then $B$ without being committed one way or the other on the question of whether $A$ is true. In citing scriptural passages in support of conditionals of the aforementioned form, one would no more be committed to the truth of those passages than would a writer who cited passages from the Sutras in arguing for conditionals of the form if Buddhism were true, then $p$. Erik Wielenberg's Value and Virtue in a Godless Universe (2005) at various points exemplifies approach (2). Wielenberg cites a number of scriptural passages when comparing the understanding of humility that he sees as flowing from the Biblical worldview with his own preferred secular conception of humility, ultimately arguing that the latter, even though lacking God as its point of reference, is still sufficiently robust to motivate charity towards others. Wielenberg seeks only to show what Christian theism is committed to when it comes to the topic of humility; he has no need at all to presuppose the truth of the scriptural passages he cites.

One sort of project that is frequently carried out under the banner of analytic theology involves taking an important doctrinal claim as formulated in the creeds - the Trinity and Incarnation, say-and seeking to present a logically coherent model of that doctrine, the ultimate aim being to demonstrate that contrary to the critics' accusations, the doctrine in question is not an impossibility. Several examples of this sort of undertaking can be found in Volume 1 of Oxford Readings in Philosophical Theology (Rea 2009b). Peter van Inwagen, for instance, begins his essay in that volume in the following way: "I shall try to imagine a way of stating the doctrine of the Trinity that has the following feature: when the doctrine is stated in this way, it can be shown not to be self-contradictory" (2009: 61). Where does this sort of project fit into my taxonomy? I am tempted to say that it exemplifies approach (2). The author is concerned to describe a model, a set of propositions, which both entails the doctrinal claim that the author ascribes to the Christian theological tradition-in this case, the claim that God exists in three persons-and seems clearly to be metaphysically possible. Since $p$ entails $q$ and possibly $p$ taken together entail possibly $q$, the author, if successful, will have demonstrated the metaphysical possibility of the three-in-one claim. Insofar as any mention of scriptural passages or creedal affirmations is made in undertaking such a task, as far as I can see it really serves only the purpose of illustrating what it is that orthodox Christianity is committed to-for instance, the claim that God is three persons. That is, it seems that references to scripture or creedal affirmations are not, in this context, being offered as premises in support of the truth (and hence the possible truth) of the doctrinal claim that is under consideration; rather, the author has taken it upon him or herself to try to demonstrate the possible truth of the doctrinal claim in question by using as premises the deliverances only of those sources that secular philosophers will generally regard as legitimate.

\footnotetext{
${ }^{9}$ I mean to include here conditionals of the form if Christian theism were true, then possibly $p$.
} 
Let's now turn to consider forms of analytic theology that appeal to scripture and tradition by using claims found therein as premises in arguments. As is suggested by the number of sub-varieties of this approach that I have delineated, it seems to me that things become a little more complicated at this point. Before going further, though, it's worth pausing to consider whether there's actually much of a difference between approach (2) and approaches that use scriptural claims as premises. Alvin Plantinga has suggested that for any argument that employs scriptural premises, one can always employ a counterpart argument which remains neutral on the truth of the scriptural claims at issue and instead aims for a merely conditional conclusion concerning what would follow if those scriptural claims were true (i.e. exactly the sort of conclusion which I said approach (2) seeks to establish). He describes an approach he calls 'conditionalization' wherein:

Instead of addressing a given question, 'What is the best way to think about $x$, employing all that you know including what you know by faith?' you address instead the question 'What would be the best way to think about $x$, if in fact the deliverances of the faith were true?' This question can be approached Duhemianly (or Spinozistically), using only beliefs that are among the deliverances of reason; no theological assumptions or deliverances of faith need be involved... Your results can be displayed as a conditional if $F$, then $P$; where $F$ represents the deliverances of faith. (2000: 419)

Plantinga is clearly right in what he says here, but it would be a mistake to suppose that just because one can very easily switch from an approach that treats scriptural claims as premises to an approach that merely considers what would follow if those scriptural claims were true (irrespective of whether they are true)-i.e. approach (2) - that there is therefore no significant difference between these two sorts of approach. Consider that if the conclusion of one's argument is merely a conditional of the form if Christian scripture were trustworthy, then $p$, then one won't, on the basis of such an argument, be entitled to believe $p$. By contrast, if one's argument combines a conditional of the form if Christian scripture were true, then $p$ with the premise that Christian scripture (or at least the relevant portion thereof) is true, then provided one is entitled to that premise-and approaches (4), (5), (6), and (7) take different stances on whether and in what manner one needs to argue for that premise-one will be entitled on the basis of one's argument to believe $p$. And that is surely a very important difference. A fully fledged Christian faith cannot consist merely in believing conditionals of the aforementioned sort; it presumably also involves believing the consequents of at least some such conditionals.

We can now turn to consider those approaches which don't merely conditionalize but which argue from premises which include scriptural claims. Let's start with what seems to be the easiest judgment call, namely, whether a form of analytic theology that appeals to scripture and tradition in way (3) is distinct from analytic philosophy of religion at the level of methodology. The answer seems to be a clear 'yes.' To treat Christian scripture and tradition as epistemologically foundational is certainly to part ways with the methodology of analytic philosophy of religion. But why exactly is that? The reason, I suspect, has 
to do with the overarching aspirations of analytic philosophy. Analytic philosophy, including analytic philosophy of religion, aspires to a certain kind of universality: analytic philosophy, I take it, is supposed to be the kind of activity that any sufficiently intelligent rational creature in any possible world could (at least in principle) engage in, given the right sort of training, and so on. ${ }^{10}$ Given this, any epistemic source which analytic philosophy treats as foundational ought to be such that it is in principle available to just about any sufficiently intelligent rational creature. But divine revelation is by its very nature not part of the natural cognitive endowment of any finite rational creature, and for that reason it cannot be treated as a foundational epistemic source by an analytic philosopher qua analytic philosopher. It seems, then, that a form of analytic theology that appeals to scripture and tradition in way (3) is clearly distinguished by virtue of its methodology from analytic philosophy of religion. Notably, Karl Barth held that it is proper to treat scripture as a source whose trustworthiness need not and indeed should not be established by reference to some allegedly more basic epistemic source-hence his passionate opposition to the project of natural theology. Barth cannot rightly be thought of as a practitioner of any form of analytic theology, ${ }^{11}$ but an approach which takes a broadly Barthian attitude to the status of scripture as an epistemic source and combines it with the use of the analytic tools described earlier would exemplify approach (3).

We now come to what I take to be the somewhat trickier questions of whether forms of analytic theology that use scriptural or tradition-based claims as intermediate premises are distinct from analytic philosophy of religion the level of methodology. To use scriptural or tradition-based claims as intermediate premises is to cite them in support of one's conclusions whilst also attempting to offer some kind of reasoned justification for one's employment of scripture or tradition, and this seems on the face of it to be a step in the direction of analytic philosophy of religion. But how big a step? As a guiding principle here, I would suggest that the more that a form of analytic theology attempts to make scripture and tradition answerable to those philosophically-approved cognitive faculties which are available to more-or-less any sufficiently intelligent rational creatureempirical observation, induction, inference to the best explanation, a priori intuition, and so on-the more closely it will resemble analytic philosophy of religion at the level of methodology.

Of the four ways of using scripture and tradition as intermediate premises that I have identified, (4) seems to be the closest methodologically to analytic philosophy of religion. This approach singles out particular claims made by scripture or tradition and seeks to argue for those claims by reference just to the aforementioned sorts of cognitive faculties and sources. It isn't surprising that Christian writers seeking to engage in apologetic efforts directed at nonbelievers-defending the historicity of the Resurrection or the Incarnation, for example-tend to approach scripture in just this manner for such purposes. Prime

\footnotetext{
${ }^{10}$ Again, see Bealer (1998: 203-204).

${ }^{11}$ As Oliver Crisp writes, "It is more difficult to see how a Barth-like method might be analytic. His whole approach to theology, as John Webster suggests, is much more like a fugue that uses variations on a theme in different parts of the work to make sense of a theological topic" (2009: 46).
} 
examples of this approach are the arguments for the historicity of the Resurrection offered by Richard Swinburne (2003) and William Lane Craig (1985). Roughly, the strategy of these authors is to argue that a bodily resurrection of Jesus is the best explanation for a range of occurrences reported in Paul's epistles and the Gospels, such as the burial of Jesus, the subsequent discovery of his tomb empty by his women followers, and the experiences had by the disciples of seeming to see Jesus after his death. Further argumentation is offered on behalf of the trustworthiness of each of the scriptural passages at issue, and that argumentation doesn't itself assume the trustworthiness of scripture or any portion thereof.

Similar remarks apply to (6), which seeks to argue for the trustworthiness of scripture and tradition by reference only to such philosophically-approved cognitive faculties. The slight difference is that (6) seeks to show that scripture and tradition are trustworthy as a whole without engaging in a defence of each and every scriptural or tradition-based claim that is being used. In that sense, approach (6) makes those sources slightly less answerable to the aforementioned faculties than does approach (4).

Finally, let's consider approaches (5) and (7). In terms of their resemblance to the methodology of analytic philosophy of religion, these two approaches stand somewhere in between (3), on the one hand, and (4) and (6), on the other. Approaches (5) and (7) both seek to offer some reasoned justification for the use of scriptural or tradition-based claims as premises, but the reasoning in question is epistemically circular in the sense defined earlier, namely, that such approaches argue for the trustworthiness of scripture or tradition (as a whole, in the case of (7); for particular claims made therein, in the case of (5)) in a manner that relies in part on claims made by those very sources. Now, I noted earlier that some epistemologists regard some instances of epistemic circularity as benign and even virtuous. Coherentists about epistemic justification, in fact, think that there isn't an alternative, short of radical scepticism, to arguing in a circle for the reliability of any given cognitive faculty or source, since coherentists hold that no cognitive faculty or source may be treated as foundational (i.e. as being such that we may employ it without having any prior reason to trust it). ${ }^{12}$ Insofar as it is possible to be epistemically justified in trusting a given faculty or source on the basis of epistemically circular reasoning, it is intuitively plausible that some circles yield more justification than others. In particular, it is plausible that bigger circles are better, other things held equal. An argument for trusting scripture which immediately appeals to scriptural passages and nothing else-which appeals, for instance, to the Pauline passage according to which "All Scripture is God-breathed and is useful for teaching, rebuking, correcting and training in righteousness" (2 Timothy 3: 16-17) - will involve a very small justificatory circle-so small, indeed, that it is tempting to see such an approach as really treating scripture as epistemologically foundational and hence being an instance of approach (3). On the other hand, an argument for the trustworthiness of scripture that appeals in the first instance to a variety of independent sources-certain aesthetic or moral intuitions or observations about human nature, for instance-and only later appeals to scripture or tradition in order to argue for the trustworthiness of these independent sources, will yield considerably more justification (insofar as

\footnotetext{
${ }^{12}$ Appropriately, those epistemologists who think that we can employ some cognitive faculties or sources without prior reason for trusting them are called 'foundationalists.'
} 
epistemically circular reasoning yields justification at all). This latter sort of circularity still doesn't make scripture and tradition fully answerable to philosophically-approved sources and so it can be seen to diverge from the methodology of analytic philosophy of religion, but not quite as sharply as does a form of analytic theology that employs approach (3).

\section{Conclusion}

I hope to have shed a little light in the foregoing remarks on the relationship between analytic philosophy of religion and analytic theology. According to my account there are in fact several possible forms of analytic theology, each of which differ from one another with respect to the epistemological status that they accord to scripture and tradition. If I am correct in thinking that the suspicion of some non-analytic theologians towards the project of analytic theology has something to do with the worry that it isn't genuinely distinct from analytic philosophy of religion and hence isn't really theology, then it behooves those calling themselves analytic theologians to be fully explicit about the epistemological role played by scripture and tradition in their methodologies, and hence, about whether or not they are practicing a form of analytic theology of which that worry is correct. ${ }^{13}$

\section{Bibliography}

Abraham, William J. 2013. "Turning Philosophical Water into Theological Wine." Journal of Analytic Theology 1: 1-16. doi:10.12978/jat.2013$1.220812000112^{\mathrm{a}}$.

Alston, William P. 1986. "Epistemic Circularity." Philosophy and Phenomenological Research 47: 1-30. 1991. Perceiving God: The Epistemology of Religious Experience. Cornell University Press.

Aquinas, Thomas. 1981 [1273]. Summa Theologiae. Translated by the English Dominican Fathers. Burns, Oates, and Washburne.

Bealer, George. 1998. "Intuition and the Autonomy of Philosophy." In Rethinking Intuition: The Psychology of Intuition and Its Role in Philosophical Inquiry, edited by Michael DePaul and William Ramsey. 201-40. Rowman and Littlefield.

Borg, Marcus J. and Wright, N.T. 2000. The Meaning of Jesus: Two Visions. Harper Collins.

\footnotetext{
${ }^{13}$ I am very grateful to Isaac Choi, Kate Kirkpatrick, James Crocker, and an anonymous referee for their incisive comments on this paper, and to the participants of the 2015 Helsinki Analytic Theology Symposium for their questions and comments on an ancestor of this paper.
} 
Chignell, Andrew. 2009. “'As Kant Has Shown': Analytic Theology and the Critical Philosophy." In Analytic Theology: New Essays in the Philosophy of Theology, edited by Oliver D. Crisp and Michael C. Rea. 117-35. Oxford University Press.

Craig, William Lane. 1985. "The Historicity of the Empty Tomb of Jesus." New Testament Studies 31: 39-67. doi:10.1017/S0028688500012911.

Crisp, Oliver D. 2009. “On Analytic Theology.” In Analytic Theology: New Essays in the Philosophy of Theology, edited by Oliver D. Crisp and Michael C. Rea. 33-53. Oxford University Press.

Leftow, Brian. 1991. Time and Eternity. Cornell University Press.

Lewis, David. 1997. “Do We Believe in Penal Substitution?” Philosophical Papers 26 (3): 203-09.

Mackie, J. L. 1982. The Miracle of Theism: Arguments for and against the Existence of God. Oxford University Press.

Plantinga, Alvin. 1992. "Augustinian Christian Philosophy." The Monist 75: 291320. doi: 10.5840/monist199275319.

2000. Warranted Christian Belief. Oxford University Press.

Rea, Michael. 2009a. "Introduction." In Analytic Theology: New Essays in the Philosophy of Theology, edited by Oliver D. Crisp and Michael C. Rea. 1-30. Oxford University Press.

ed. 2009b. Oxford Readings in Philosophical Theology: Trinity, Incarnation, Atonement. Vol. 1. Oxford University Press.

Sosa, Ernest. 2009. Reflective Knowledge. Vol. 2, Apt Belief and Reflective Knowledge. Oxford University Press.

Stump, Eleonore. 2013. "Athens and Jerusalem: The Relationship of Philosophy and Theology." Journal of Analytic Theology 1: 45-59. doi:10.12978/jat.2013-1.041104181915a.

Swinburne, Richard. 2003. The Resurrection of God Incarnate. Clarendon Press. 2004. The Existence of God. 2nd ed. Oxford University Press.

Van Cleve, James. 2003. "Is Knowledge Easy or Impossible? Externalism as the Only Alternative to Skepticism." In The Skeptics: Contemporary Essays, edited by Steven Luper. 45-59. Ashgate. 
van Inwagen, Peter. 2006a. The Problem of Evil: The Gifford Lectures Delivered in the University of St Andrews in 2003. Oxford University Press.

. 2006b. "What Is Naturalism? What Is Analytical Philosophy?" In Analytic Philosophy without Naturalism, edited by Antonella Corradini, Sergio Galvan and E. Jonathan Lowe. 74-88. Routledge.

2009. "Three Persons in One Being: On Attempts to Show That the Doctrine of the Trinity Is Self-Contradictory." In Oxford Readings in Philosophical Theology: Trinity, Incarnation, Atonement, edited by Michael Rea. 61-75. Oxford University Press.

Wielenberg, Erik J. 2005. Value and Virtue in a Godless Universe. Cambridge University Press.

Williamson, Timothy. 2007. The Philosophy of Philosophy. Blackwell.

Wolterstorff, Nicholas. 2009. "How Philosophical Theology Became Possible within the Analytic Tradition of Philosophy." In Analytic Theology: New Essays in the Philosophy of Theology, edited by Oliver D. Crisp and Michael C. Rea. 155-68. Oxford University Press.

Wood, William. 2014. "Analytic Theology as a Way of Life." Journal of Analytic Theology 2: 43-60. doi:10.12978/jat.2014-1.220812221403a. 